\title{
EFFECTS OF LITTER SIZE AND MATERNAL WEIGHT ON FOETAL AND PLACENTAL WEIGHT IN MICE
}

\author{
J. C. MaGARTHY \\ Faculty of Agriculture, University College, Glasnevin, Dublin
}

(Received 28th Fuly 1967)

\begin{abstract}
Summary. A summary of several estimates of the partial regressions of foetal weight and placental weight at $17 \frac{1}{2}$ days gestation on (i) the number of implants in a uterine horn and (ii) the number of implants in a whole litter is presented for litters of one outbred stock and four highly inbred lines of mice. These estimates suggest that the effects of litter size on foetal and placental size are similar in different inbred lines but that (a) the systemic effect of litter size on foetal growth is different and (b) the local effect of implants number on placental growth is different, at least until the 17 th day of gestation, in the outbred stock.
\end{abstract}

In this communication I have summarized several estimates of partial regression coefficients obtained by routine analysis of mouse data at two laboratories (Edinburgh, Institute of Animal Genetics and Dublin). The partial regression coefficients referred to are measures of the independent relationships between (a) mean foetal weight at $17 \frac{1}{2}$ days gestation or (b) mean placental weight and (i) the number of implants in a uterine horn, (ii) the number of implants in the litter as a whole and (iii) the weight of the mother at about the time of mating. Data were obtained by dissecting pregnant mice 17 days post coitum and weighing the foetuses and placentae from each horn separately. Data were collected during the course of two different experiments on the genetics of prenatal growth. One experiment, completed at Edinburgh, involved four different highly inbred lines (for details see McCarthy, 1965). The other experiment, which is nearly completed here, involved an outbred stock, designated the Q-strain, and partially inbred material derived from this (for details, see McCarthy, 1967) and one of the four inbred lines referred to above. Estimates from both the outbred population of $Q$ mice and the related partially inbred material (which was, on average, about $25 \%$ inbred) are classified here as 'Q-strain'. Estimates from the inbred line, which was not affected in any way by the change of location, are classified with those from the highly inbred lines referred to above.

The results of several multiple regression analyses, each of which was based on data from about forty to seventy pregnancies and performed separately for purposes of within-generation group comparisons, are summarized in Tables 1 and 2. The main points of interest are: 
1. Estimates of the partial regression of mean foetal weight in a uterine horn on the number of implants in the whole litter $\left(a_{2}\right.$, in Table 1) were mostly positive in the $Q$ stock but mostly negative in the highly inbred stocks. Exceptions to this generalization were not statistically significant; the arithmetic means of the estimates were +0.5 and -0.9 centigrams/implant for the $Q$ strain and the highly inbred lines, respectively.

\section{TABLE 1}

SUMMARY OF MULTIPLE REGRESSIONS OF FOETAL WEIGHT AT $17 \frac{1}{2}$ DAYS GESTATION ON THE NUMBER OF IMPLANTS IN THE HORN $\left(a_{1}\right)$, ON THE NUMBER IN THE LITTER (a $\left.a_{2}\right)$ AND ON MATERNAL WEIGHT $\left(a_{3}\right)$

\begin{tabular}{|c|c|c|c|c|c|}
\hline \multirow{2}{*}{ Stock } & \multirow{2}{*}{$\begin{array}{l}\text { Regression } \\
\text { coefficient }\end{array}$} & \multicolumn{3}{|c|}{ Number of estimates } & \multirow{2}{*}{$\begin{array}{c}\text { Average } \\
\text { estimate } \\
(\mathrm{g} \times 100)\end{array}$} \\
\hline & & Total & $\begin{array}{l}\text { Positivel } \\
\text { significant }\end{array}$ & $\begin{array}{l}\text { Negativel } \\
\text { significant }\end{array}$ & \\
\hline Q-strain & $\begin{array}{l}a_{1} \\
a_{2} \\
a_{3}\end{array}$ & 11 & $\begin{array}{l}2 / 0 \\
9 / 2 \\
8 / 0\end{array}$ & $\begin{array}{l}9 / 6 \\
2 / 0 \\
3 / 0\end{array}$ & $\begin{array}{l}-0.9 \\
+0.5 \\
+0.2\end{array}$ \\
\hline Highly inbred lines & $\begin{array}{l}a_{1} \\
a_{2} \\
a_{3}\end{array}$ & $10 \dagger$ & $\begin{array}{c}\text { None } \\
1 / 0 \\
9 / 4\end{array}$ & $\begin{array}{r}10 / 6 \\
9 / 4 \\
1 / 0\end{array}$ & $\begin{array}{l}-1.5 \\
-0.9 \\
+1.0\end{array}$ \\
\hline
\end{tabular}

* Number of estimates which were significant at $P=0.05$, at least.

$\uparrow$ Comprises two independent estimates from three inbred lines and four independent estimates from one inbred line.

TABLE 2

SUMMARY OF MULTIPLE REGRESSIONS OF PLAGENTAL WEIGHT AT $17 \frac{1}{2}$ DAYS GESTATION ON THE NUMBER OF IMPLANTS IN THE HORN $\left(b_{1}\right)$, ON THE NUMBER IN THE LITTER $\left(b_{2}\right)$ AND MATERNAL WEIGHT $\left(b_{3}\right)$

\begin{tabular}{|c|c|c|c|c|c|}
\hline \multirow{2}{*}{ Stock } & \multirow{2}{*}{$\begin{array}{l}\text { Regression } \\
\text { coefficient }\end{array}$} & \multicolumn{3}{|c|}{ Number of estimates } & \multirow{2}{*}{$\begin{array}{c}\text { Average } \\
\text { estimate } \\
(g \times 1000\end{array}$} \\
\hline & & Total & $\begin{array}{c}\text { Positivel } \\
\text { significant }\end{array}$ & $\begin{array}{l}\text { Negativel } \\
\text { significant }\end{array}$ & \\
\hline Q-strain & $\begin{array}{l}b_{1} \\
b_{2} \\
b_{3}\end{array}$ & 11 & $\begin{array}{c}\text { None } \\
1 / 0 \\
11 / 4\end{array}$ & $\begin{array}{l}11 / 0 \\
10 / 6 \\
\text { None }\end{array}$ & $\begin{array}{l}-1.0 \\
-1.7 \\
+1.5\end{array}$ \\
\hline Highly inbred lines & $\begin{array}{l}b_{1} \\
b_{2} \\
b_{3}\end{array}$ & 10 & $\begin{array}{r}10 / 1 \\
\text { None } \\
8 / 4\end{array}$ & $\begin{array}{r}\text { None } \\
10 / 9 \\
2 / 0\end{array}$ & $\begin{array}{r}+1.0 \\
-3.0 \\
+1.3\end{array}$ \\
\hline
\end{tabular}

* Number of estimates significant at $P=0.05$, at least.

2. Estimates of the partial regression of mean placental weight in a uterine horn on the number of implants in the horn $\left(b_{1}\right.$, in Table 2) although not individually statistically significant were all negative in the $Q$ stock and all positive in the highly inbred stocks; the arithmetic means of the estimates were -1.0 and $+1.0 \mathrm{mg} / \mathrm{implant}$ for the $Q$ strain and the highly inbred lines, respectively. 
3. Estimates of the partial regression of mean foetal weight on number of implants in a uterine horn $\left(a_{1}\right)$ and on maternal weight $\left(a_{3}\right)$ and of the partial regression of mean placental weight on the number of implants in the whole litter $\left(b_{2}\right)$ and on maternal weight $\left(b_{3}\right)$ were, in general, fairly repeatable in the $Q$ stock and consistent for both the $Q$ stock and highly inbred lines.

Both McLaren (1965) and I (McGarthy, 1965) have published results typical of those presented here for the highly inbred lines; all our results referred to data collected 17 days post coitum and the mothers were in all cases representatives of recognized laboratory inbred strains. I, in particular, tended to generalize about these results in terms of the occurrence of local and systemic effects of litter size on prenatal growth. We inferred that the growth of a mouse foetus is retarded independently (a) by increase in the number of implants in the same horn and, (b) by increase in the number in the litter; (a) and (b) were referred to as local and systemic effects, respectively.

There is certainly no evidence of a negative systemic effect of litter size on foetal weight in the litters of the $Q$ mice. What is even more disconcerting is that the evidence suggests that the independent relationship between foetal weight and total litter size is of opposite sign in the litters of two genetically different groups of mice. It is intended to examine these relationships at different times of gestation in the Q-strain, in one of the highly inbred lines referred to here and, if possible, in highly inbred lines derived from the Q-strain to investigate (i) the possibility that this anomalous result is an artifact of the standardized stage of gestation at which foetuses were weighed or (ii) that inbreeding affects the mother in some way that influences the relationships between litter size and the rate of prenatal growth. At this stage, however, these results serve to put the problem of postulating the physiological basis of variation in the foetal growth of even one species into perspective.

The second odd feature of these results is that estimates of the partial regression of placental weight on number of implants in a uterine horn were consistently different in sign for the $Q$ stock and the highly inbred lines. McLaren and I were puzzled by the repeated occurrence of positive but statistically insignificant estimates of this regression in separate analyses of data from litters of quite different inbred lines. All estimates of this regression from one of the highly inbred lines have since been positive but, as shown in Table 2, all estimates of the regression in litters of $Q$ mice were negative and insignificant. The inference of a real difference between stocks in this parameter is, perhaps, justified. The question of why this difference occurs is just as difficult as that posed by the other anomalous set of results described above.

Finally, it is reassuring, at least, that evidence of (i) a negative local effect of implant number on foetal weight, (ii) a negative systemic effect of implant number on placental weight and (iii) a positive relationship between foetal or placental weight and maternal weight, is consistent in all the data.

I would like to thank Dr Anne McLaren for helpful discussion of the presentation of these results. 


\section{REFERENCES}

McCarthy, J. C. (1965) Genetic and environmental control of foetal and placental growth in the mouse. Anim. Prod. 7, 347.

McCarthy, J. C. (1967) The effects of inbreeding on the components of litter size in mice. Genet. Res. $10,73$.

MaLAREN, A. (1965) Genetic and environmental effects on foetal and placental growth in the mouse. 7. Reprod. Fert. 9, 79. 